\title{
Effects of serotonin on rat ileocolonic transit and fluid transfer in vivo: possible mechanisms of action
}

\author{
L Oosterbosch, M von der Ohe, M A Valdovinos, L J Kost, S F Phillips, M Camilleri
}

\begin{abstract}
The aim was to investigate the action of serotonin (5HT) on function of the ileocolonic junction (ICJ) in vivo. In anaesthetised rats, models were developed to study the effects of intra-aortic (ia) serotonin on ileocolonic and colonic transit, and the effects on transit of a number of 5HT receptor antagonists. In the first series of experiments, a bolus of saline labelled with ${ }^{99 m}$ Tc DTPA was instilled $20 \mathrm{~cm}$ proximal to the ICJ and transit was assessed three hours later by the geometric centre of the spread of isotope. In the second series, similar techniques were used on the postcaecal colon and transit assessed two hours later. In the third series of experiments, the effects of ia 5HT on ileal net fluid flux was evaluated by standard perfusion experiments with ${ }^{14} \mathrm{C}$ polyethylene glycol (PEG) 4000 as a non-absorbable marker in rat plasma-like electrolyte solution. Compared with ia saline, 5HT accelerated ICJ transit significantly $(\mathbf{p}<0.05)$. This acceleration was comparable with the effect of ia bethanechol. The effects of $5 \mathrm{HT}$ on ICJ transit were inhibited by the intraperitoneal (ip) infusion of atropine, the $5 \mathrm{HT}$ receptor antagonists, methysergide, ketanserin, zacopride, and the $\mathbf{5 H T}_{4}$ agonist, SC53116. Methysergide, zacopride, and SC53116 given with ia 5HT slowed ICJ transit to rates below those of ia saline alone. When these same agents were given together with ia saline, the ICJ transit was not significantly altered. Serotonin, at the dose that accelerated ICJ transit, did not significantly alter colonic transit or ileal fluid transport. In conclusion, 5HT is a potent pharmacological stimulant of transit across the rat ICJ in vivo; the action of $5 \mathrm{HT}$ is mediated partly through muscarinic neurones and several 5HT receptor subtypes.

(Gut 1993; 34: 794-798)
\end{abstract}

Serotonin (5 hydroxytryptamine, 5HT) is believed to be an important humoral mediator of carcinoid diarrhoea. ${ }^{1-3}$ Agents that release 5HT exacerbate diarrhoea in the carcinoid syndrome ${ }^{2}$; agents that block the synthesis or the peripheral effects of 5HT sometimes control diarrhoea in patients with carcinoid syndrome. ${ }^{+8}$ Serotonin stimulates contraction or myoelectric spike activity of small intestinal muscle in vivo, ${ }^{910}$ and gastrointestinal transit is altered in patients with the carcinoid syndrome."12 Serotonin also stimulates gastric emptying in rats in vivo ${ }^{13}$; however, the specific effects of 5HT on propulsion and transit in vivo are less clear.

In an in vitro study of an isolated segment of guinea pig ileum, Bülbring and Lin found that 5HT stimulated propulsive motility when applied intraluminally. ${ }^{14}$ By contrast, serosal 5HT had no effect on transit ${ }^{14}$; others have even reported inhibition of peristalsis by $5 \mathrm{HT} . .^{15}$ Serotonin stimulates nerve muscle preparations from the guinea pig small intestine and colon in vitro. ${ }^{16}$ Thus there is evidence that $5 \mathrm{HT}$ can both inhibit and facilitate gastrointestinal motor function.

Intestinal smooth muscle cells and enteric nerves have $5 \mathrm{HT}_{1}, 5 \mathrm{HT}_{2}$, and $5 \mathrm{HT}_{3}$ receptors. ${ }^{17}$ More recently, a new class of $5 \mathrm{HT}_{4}$ receptors $^{18}$ has been found in several tissues, including the guinea pig ileum ${ }^{1920}$ and ascending colon, ${ }^{21}$ the cardiovascular system of the pig,,$^{223}$ and the human heart. ${ }^{24}$ Acetylcholine is thought to play an important part in mediating 5HT induced contraction of intestinal smooth muscle in vitro ${ }^{25}$ and in vivo. ${ }^{14}$ The relative roles of the different subtypes of 5HT receptors inducing propulsion through different levels of the alimentary tract are unclear. Further understanding of serotonergic control of motility could lead to new ways to control diarrhoea in diseases such as the carcinoid syndrome.

The ileocolonic junction (ICJ) is an important area whereby gastrointestinal absorptive and motor functions are controlled, by virtue of its regulation of the passage of chyme from the small to the large bowel. ${ }^{26}$ In carcinoid diarrhoea, transit through the small bowel and proximal colon is considerably accelerated, ${ }^{27}$ and this acceleration is associated with high urinary concentrations of 5-hydroxyindole-acetic acid (5HIAA) and circulating 5HT. ${ }^{3}$ In view of the rapid ICJ transit in patients with carcinoid diarrhoea, ${ }^{13}$ our aim was to develop a model in which the effects and mechanisms of hyperserotoninaemia on transit and fluid transport in this region could be investigated.

\section{Materials and methods}

Experiments were performed on 100 adult male Sprague-Dawley rats weighing $300-400 \mathrm{mg}$; the study was approved by the institutional animal care and use committee and the radiation control committee of the Mayo Clinic. Animals were housed in an animal care facility that is approved by the American Association for Accreditation of Laboratory Animal Care and they were exposed to 12 hours of alternating light and dark cycles. Their health was monitored by fully trained veterinary staff.

\section{EXPERIMENTAL PROCEDURES}

\section{Preparation of experimental models}

Rats were anaesthetised with intraperitoneal (ip) chloral hydrate $(300 \mathrm{mg} / \mathrm{kg})$. In all animals, a 
tracheostomy was performed to allow endotracheal intubation and mechanical ventilation by a rodent ventilator (cat no 7025, Stollting Co, Chicago, IL). The respiratory minute volume was never higher than $0 \cdot 12$ litres and the frequency of respiration was set at 60 a minute. A PE10 cannula was placed into the thoracic aorta through a cutdown into the left carotid artery.

Rats also underwent laparotomy, at which time several models were established. In the first (for ileocolonic transit), a Tygon cannula (external diameter: $1.22 \mathrm{~mm}$; internal diameter: $0.76 \mathrm{~mm}$ ) was placed into the distal ileum about $20 \mathrm{~cm}$ from the caecum, the caecum was opened, and the ileocaecal segment was rinsed of any residue with warm saline $\left(37^{\circ} \mathrm{C}\right)$. After closing the caecum with a purse string ligature, the loops of intestine were restored to the abdominal cavity. In experiments on the colon (colonic transit), one cannula was positioned in the postcaecal portion of the colon; a second cannula was placed in the most distal part of the colon that was accessible at the time of laparotomy. The average length of the colonic loop studied was $20 \mathrm{~cm}$. In a third series of experiments (fluid transport), the distal 20 to $25 \mathrm{~cm}$ of ileum was isolated for perfusion studies by two Tygon cannulae. After one of these three experimental segments was set up, the intestines were returned to the abdominal cavity and the incision was closed.

\section{Ileocolonic transit}

One $\mathrm{ml}$ of ${ }^{99 \mathrm{~m}} \mathrm{Tc}$ DTPA radio labelled saline was introduced into the ileum by slow infusion over five minutes; $0.3 \mathrm{ml}$ saline was gently flushed through the cannula to ensure delivery of the entire volume of radiolabel into the ileum. Preliminary studies showed that, with this method of delivery, the radiolabel did not disperse beyond the first $5 \mathrm{~cm}$ of the ileal segment. Animals were kept under light anaesthesia thereafter with ip chloral hydrate. Three hours after the ileal infusion, the abdomen was opened and the mesenteric vessels were tied. The ileocolonic segment was identified, closed by ligatures at each end, and divided into five equal portions by separating $4 \mathrm{~cm}$ segments by means of silk ligatures. The caecum and colon were identified down to the pelvis and ligatures tied. The rats were then killed, and all these segments were counted in a Capintech radioisotope dose calibrator (CRC-5, Montvale, NJ).

\section{Colonic transit}

With the animals under light anesthaesia, $1 \mathrm{ml}$ of ${ }^{99} \mathrm{~m}$ Tc DTPA radiolabelled saline was introduced into the colon by slow infusion over five minutes; $0.3 \mathrm{ml}$ of saline was gently flushed through the cannula. Two hours after this infusion, the abdomen was opened, and the loop of colon was divided into four equal segments by means of silk ligatures. The effluent from the distal Tygon cannula was collected separately during the experiment, and constituted the fifth segment. Each segment of colon and the effluent were counted in a dose calibrator.

\section{Ileal fluid transport}

The ileum was perfused through the proximal cannula with an iso-osmolar electrolyte solution containing ${ }^{14} \mathrm{C}$ PEG 4000 . The electrolyte content $\left(\mathrm{Na}^{+}, 151 \mathrm{mmol} / \mathrm{l} ; \mathrm{K}^{+}, 5.6 \mathrm{mmol} / \mathrm{l} ; \mathrm{Cl}^{-}\right.$, $128 \mathrm{mmol} / \mathrm{l} ; \mathrm{Ca}^{++}, 2.5 \mathrm{mmol} / 1 ; \mathrm{HCO}_{3}{ }^{-}, 23 \cdot 1$ $\mathrm{mmol} / \mathrm{l}$ ) was selected to mimic rat plasma (osmolarity: $324 \mathrm{mOsm} / \mathrm{kg}$; pH, 7.4). The ileal loop was perfused at a rate of $1.0 \mathrm{ml} /$ minute by a peristaltic pump (Watson-Marlow Inc, Marblehead, MA); experiments started with 30 minutes equilibration followed by three hours during which samples of ileal effluent were collected every 10 minutes. During the first and third hours, saline was infused into the aorta; during the second hour, 5HT was infused. Net fluid flux was assessed by changes in the concentration of the non-absorbable marker, ${ }^{14} \mathrm{C}$ PEG 4000.

\section{Choice of agonist and antagonist doses}

The dose of 5HT (Sigma Chemical Co, St Louis, MO) used in this study $(7 \cdot 74 \mathrm{mmol} / \mathrm{kg})$ was based on previous in vivo dose response studies that showed that 5HT stimulated gastric emptying. ${ }^{28}$ Antagonist doses were based on previous publications. ${ }^{29-32}$ In the first series of experiments on motor function of the ileocolonic junction, we studied the effects of ia saline, $5 \mathrm{HT}$, and bethanechol chloride, at a dose of $3.05 \mathrm{mmol} / \mathrm{kg}$ (Merck, Sharp, and Dohme, West Point, PA). These agents were given in a total volume of $1.5 \mathrm{ml}$, a $0.5 \mathrm{ml}$ bolus injection, followed by a continuous infusion of $1 \mathrm{ml}$ over a one hour period.

In experiments to study the mechanism of $5 \mathrm{HT}$ induced alterations of ileocolonic function, atropine and several 5HT receptor subtype antagonists were given intraperitoneally 60 minutes before the laparotomy; these were atropine sulphate $(0.14 \mathrm{mmol} / \mathrm{kg}$, Elkins-Sinn, Cherry Hill, $\mathrm{NJ})$; methysergide $(2 \cdot 83 \mathrm{mmol} / \mathrm{kg}$, a $5 \mathrm{HT}_{1}$ and $5 \mathrm{HT}_{2}$ antagonist donated by Sandoz Research Institute, East Hanover, NJ, USA); ketanserin $\left(1.83 \mathrm{mmol} / \mathrm{kg}\right.$, a $5 \mathrm{HT}_{2}$ antagonist donated by Janssen Pharmaceutica Inc, Beerse, Belgium $) ; \mathrm{R}$-zacopride $(2.5 \mathrm{mmol} / \mathrm{kg}$, a selective $5 \mathrm{HT}_{3}$ antagonist donated by Searle, IL, USA), and SC53116 $\left(2.4 \mathrm{mmol} / \mathrm{kg}\right.$, a $5 \mathrm{HT}_{4}$ agonist donated by Searle, IL, USA).

\section{Experimental design}

Five series of experiments were performed in rats in vivo to study: (1) the effects of ia saline, $5 \mathrm{HT}$, and bethanechol on ileocolonic transit; (2) the effects of ip atropine, a $5 \mathrm{HT}_{4}$ agonist, and several 5HT antagonists on ileocolonic transit induced by ia $5 \mathrm{HT}$; (3) the effect of the same ip 5HT agonist and antagonists on ileocolonic transit; (4) the effect of ia saline, 5HT, and bethanechol on colonic transit; and (5) a comparison between the effects of ia saline and ia 5HT on ileal net fluid flux.

\section{DATA AND STATISTICAL ANALYSIS}

The proportions of counts in the ileal or colonic segments at the end of the experiment were calculated. ICJ transit was assessed by finding 
Figure 1: Geometric centre of isotope in the ileocolonic segment three hours after intra-aortic saline, $5 H T$, or bethanechol. Results are shown as mean (SEM).

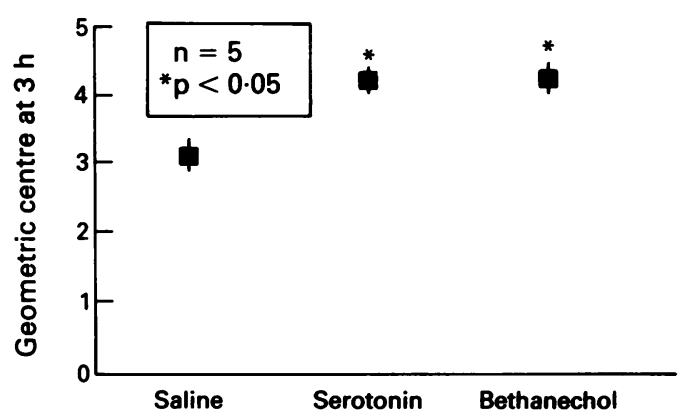

the geometric centre (weighted average) of counts over the five ileal segments, caecum, and colon with an adaptation of a previously published method used to measure intestinal transit in rats. ${ }^{33}$ For studies of ICJ transit, with this method, a value of 1 indicated that all the isotope was in the first $4 \mathrm{~cm}$ of ileum; a value of 6 indicated that all isotope was in the caecum or colon. Colonic transit was similarly assessed with the four colonic segments and effluent as the fifth segment.

Statistical analysis compared the effects on transit of 5HT and its agonist and antagonists by ANOVA followed by Dunnett's multigroup comparison, with the ia saline or the ia 5HT alone as the control groups. Effects of ip agents during ia saline were also compared by ANOVA with Newman-Kuels multigroup comparison. All results are expressed as mean (SEM).

Net fluid flux was summarised for the ia saline and 5HT hours and expressed as $\mu \mathrm{l} / \mathrm{cm}$ loop/ hour in each rat. Statistical analysis was by paired $t$ test.

\section{Results}

ILEOCOLONIC JUNCTION TRANSIT: EFFECTS OF 5HT AND ITS ANTAGONISTS

Serotonin and bethanechol (Fig 1) significantly accelerated ICJ transit compared with saline.

TABLE I Ileocolonic transit: effect of combined intra-aortic serotonin (5HT) and intreperitoneal 5HT agonist (SC53116) or $5 H T$ antagonists

\begin{tabular}{|c|c|c|c|c|}
\hline Agents & $n$ & $\begin{array}{l}\text { Isotope geometric } \\
\text { centre (mean } \\
(S E M))\end{array}$ & $p^{\star}$ & $p_{1} t$ \\
\hline Saline (ia) & 5 & $3 \cdot 1(0 \cdot 2)$ & $<0.05$ & - \\
\hline 5HT alone (ia): & 5 & $4 \cdot 3(0 \cdot 1)$ & - & $<0.05$ \\
\hline + Atropine (ip) & 5 & $2 \cdot 4(0 \cdot 2)$ & $<0.05$ & NS \\
\hline + Methysergide (ip) & 5 & $1.9(0.2)$ & $<0.05$ & $<0.05$ \\
\hline + Ketanserin (ip) & 5 & $2 \cdot 4(0 \cdot 2)$ & $<0.05$ & NS \\
\hline + R-Zacopride (ip) & 5 & $1 \cdot 6(0 \cdot 1)$ & $<0.05$ & $<0.05$ \\
\hline + SC53116 (ip) & 5 & $1 \cdot 8(0 \cdot 1)$ & $<0.05$ & $<0.05$ \\
\hline
\end{tabular}

* Significance compared with $5 \mathrm{HT}$ ia without antagonists. †Significance compared with ia saline. ia=Intra-aortic; ip=intraperitoneal.

TABLE II Ileocolonic transit: effects of serotonin (5HT) antagonists and 5HT agonist (SC53116)

\begin{tabular}{llll}
\hline ip Agentst & $n$ & $\begin{array}{l}\text { Isotope geometric } \\
\text { centre }(\text { mean }(S E M))\end{array}$ & $p \mathrm{v}$ op Saline \\
\hline Saline & 6 & $3 \cdot 0(0 \cdot 2)$ & NS \\
Methysergide & 6 & $2 \cdot 4(0 \cdot 4)$ & NS \\
Ketanserin & 6 & $2 \cdot 8(0 \cdot 4)$ & NS \\
R-Zacopride & 6 & $3 \cdot 3(0 \cdot 3)$ & NS $^{\star}$ \\
SC53116 & 6 & $2 \cdot 0(0 \cdot 3)$ & NS $^{\star}$
\end{tabular}

${ }^{\star} \mathrm{p}<0.05$ for comparison of R-Zacopride $v$ SC53116

tAll animals received a background ia infusion of saline. Abbreviations as for Table I.

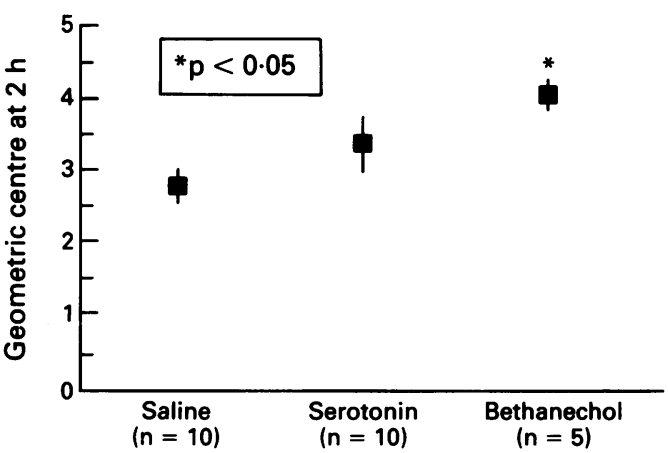

Figure 2: Geometric centre of isotope in the colon, two hours after intra-aortic saline, $5 H T$, or bethanechol. Note that bethanechol stimulates colonic transit, but $5 H T$ does not.

The effects of 5HT and bethanechol were not statistically different.

Table 1 shows the geometric centres of isotope in the ileocolonic segment after the concomitant 5HT and the series of ip drugs were given. Methysergide, R-zacopride, and SC53116 significantly inhibited the increased transit induced by $5 \mathrm{HT}$; indeed, the geometric centres of isotope with ia 5HT and these agents given ip were less than the value observed with ia saline alone (Table I). Atropine and the $5 \mathrm{HT}_{2}$ antagonist, ketanserin, also significantly inhibited 5HT induced ICJ transit, but not to concentrations below that of ia saline.

EFFECT OF INTRAPERITONEAL SC53116 AND 5HT ANTAGONISTS ON BASAL ILEOCOLONIC JUNCTION TRANSIT

None of the 5HT antagonists or the $5 \mathrm{HT}_{4}$ agonist, SC53116, significantly altered ICJ transit when they were given ip during ia infusion of saline (Table II). There were no significant differences relative to ip saline, but the difference between groups treated with SC53116 and R-zacopride was significant (Newman-Kuels test).

\section{EFFECT OF 5HT AND BETHANECHOL ON COLONIC} TRANSIT

Intra-aortic bethanechol significantly accelerated colonic transit. The effect of ia serotonin was variable; however, there was no overall acceleration of colonic transit (Fig 2).

EFFECT OF 5HT ON ILEAL FLUID FLUX

Intra-aortic 5HT, given at the same dose and route as had induced acceleration of ICJ transit, failed to significantly alter baseline absorption found during the ia infusion of saline (Fig 3).

\section{Discussion}

The questions we considered required that an in vivo model be developed for measurement of transit across the ileocolonic junction and colon. We elected to use a static rather than a dynamic method to evaluate transit because our previous studies with dynamic scintigraphy ${ }^{34}$ showed that emptying of the unprepared rat ileum into the caecum occurred very infrequently. Infusion of the liquid bolus at a slow rate ensured that the 
Figure 3: Net fluid ileal flow during infusion of saline and intra-aortic $5 H T$. Note the lack of effect of intra-aortic 5 HT (total dose $7.74 \mathrm{mmoll}$ $k g$ ).

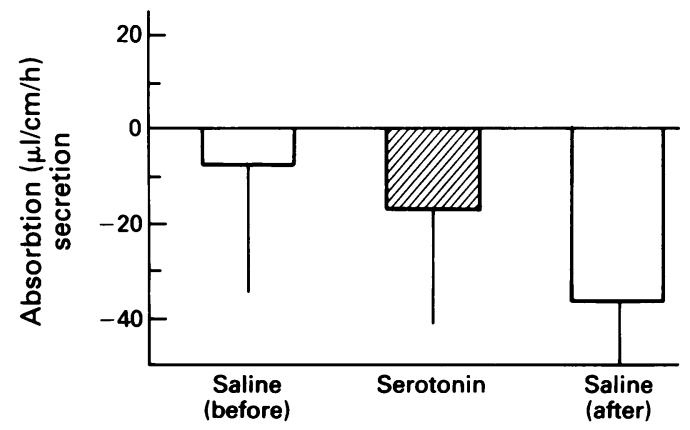

isotope did not disperse beyond the first ileal segment; the present results confirmed the effect of a cholinergic agonist and antagonist on transit in the $\mathrm{ICJ}^{35}$ and colon, suggesting that the model is valid.

Serotonin accelerated transit of liquid across the ICJ, but not in the colon in vivo. Previous reports have shown in vivo effects of 5HT on intraluminal pressure and myoelectric activity of the ICJ in the cat, ${ }^{36}$ but they did not assess the propulsive effects of $5 \mathrm{HT}$ in vivo or analyse which subtypes of $5 \mathrm{HT}$ receptors were responsible. The effects of serotonin on gastrointestinal motor function are generally believed to be mediated through myenteric plexus neurons. Although the mucosal application of 5HT activated the peristaltic reflex, ${ }^{14}$ suggesting a possible role for mucosal enterochromaffin cells, Gershon and Tamir provided convincing data that an intraenteric barrier separates the myenteric plexus from the enterochromaffin cells in the epithelium. ${ }^{37}$ It is possible, however, that mucosal application of 5HT might stimulate submucosal 5 HT neurons, ${ }^{38}$ which may in turn activate interneurons connecting the submucosal and enteric plexuses.

Effects of $5 \mathrm{HT}$ on colonic motor function were previously studied in vivo by Jacoby et al. ${ }^{39}$ Intracerebroventricular 5HT inhibited propulsive motility in the mouse colon; by contrast, ip 5HT stimulated propulsion of a glass bead through the colon. In vitro, 5HT stimulated rabbit colonic circular muscle but inhibited neurons responsible for the off contraction. ${ }^{+0}$ Others have also shown in the rat that high doses $\left(>10^{-5} \mathrm{M}\right)$ of $5 \mathrm{HT}$ relaxed the caecum ${ }^{41}$ and internal anal sphincter..$^{42}$ Our data suggest that ia 5HT had no significant physiological effect on transit of liquid through the rat colon and are, therefore, consistent with these two studies. ${ }^{41+2}$

The availability of novel, relatively specific antagonists of the 5HT receptor subtypes allowed us to evaluate the mechanism of 5HT induced acceleration of ICJ transit. Generally, our results confirm some of the findings from in vitro studies. ${ }^{39} \mathrm{We}$ showed that the effects of 5HT on ICJ transit are partially mediated by cholinergic mechanisms and that they involve several 5HT receptor subtypes. Thus 5HT stimulated an excitatory muscarinic cholinergic pathway that was inhibited by atropine. This is consistent with the previously described role of acetylcholine in 5HT induced contraction of intestinal smooth muscle in vitro ${ }^{2538}$ and in vivo, ${ }^{14}$ which is mediated through neuronal $5 \mathrm{HT}_{3}$ receptors. ${ }^{38}$ Our findings of inhibition of the $5 \mathrm{HT}$ effect by subtypes 1 and 3 antagonists and by a $5 \mathrm{HT}_{4}$ agonist suggests more complex interactions of $5 \mathrm{HT}$ receptors on enteric muscles or nerves. 5HT may be directly stimulating smooth muscle or antagonising an inhibitory interneuron in the myenteric plexus. Several motor effects of 5HT agents have been reported. For example, $5 \mathrm{HT}_{1}$ like receptors occur on enteric smooth muscle, and their stimulation resulted in smooth muscle contraction. ${ }^{434}$ Receptors for $5 \mathrm{HT}_{2}$ may alter pyloric and caecal function. ${ }^{30+1}$ Receptors for $5 \mathrm{HT}_{4}$ have been identified in neurons of guinea pig ileum ${ }^{19}$ and ascending colon ${ }^{21}$; the inhibitory effects of the $5 \mathrm{HT}_{4}$ agonist, SC53116, on 5HT induced ICJ transit in the present study suggest that there may be a $5 \mathrm{HT}_{4}$ mediated stimulation of the ileocaecal sphincter itself. The precise sites of action of 5HT were not considered in our experiments, and further studies on isolated tissues will be necessary.

Our findings help elucidate the in vivo effects of 5HT, such as in patients with carcinoid diarrhoea who have rapid small bowel and colonic transit and decreased capacitance of the proximal colon. ${ }^{27}$ Thus correction of these motor dysfunctions may help control carcinoid diarrhoea. Previous studies in a few patients suggest that carcinoid diarrhoea is, at least temporarily, improved with methysergide, ${ }^{45}$ ICS205-930 (a $5 \mathrm{HT}_{3}$ antagonist without $5 \mathrm{HT}_{4}$ effects ${ }^{16}$ ), and ketanserin. ${ }^{47}$

Intra-aortic 5HT, given at the same dose that stimulated ICJ transit, had no significant effect on net fluid flux in the rat ileum. These findings contrast with those of Beubler et al who used close intra-arterial injections of $5 \mathrm{HT} .^{+8}$ In the absence of dose-response studies, the only important point we can make is that transit was accelerated across the ICJ by a dose of ia 5HT that did not induce ileal secretion in vivo. It is possible that secretory and motor mechanisms contribute to carcinoid diarrhoea, and the effects of 5HT and its antagonists on both processes deserve further study.

We thank Cindy Stanislav for typing and preparing this manu script. This study was supported by DK32121 from Nationa Institutes of Health and by an AGA SmithKline Beecham award to Dr Camilleri. The study was presented in part at the annual meeting of the American Gastroenterological Assocation, 1992, San Francisco, California, and has been published in part abstracts in Gastroenterology 1992; 102: A251 and A398.

1 Kowlessar OD, Law DH, Sleisenger MM. Malabsorption syndrome associated with metastatic carcinoid tumor. $A m \mathcal{F}$ Med 1959; 27: 673-7.

2 Feldman JM. Carcinoid tumors and syndrome. Semin Oncol 1987; 14: 237-96.

3 Feldman JM, Plonk JW. Gastrointestinal and metabolic function in patients with the carcinoid syndrome. $A m \mathcal{F}$ Med Sci 1977; 273: 43-54.

4 Emson PC, Gilbert RFT, Martensson M, Nobin A. Elevated concentrations of substance $\mathrm{P}$ and $5 \mathrm{HT}$ in plasma in patient with carcinoid tumors. Cancer 1984; 54: 715-8.

5 Oberg K, Theodorsson-Norheim E, Norheim I. Motilin in plasma and tumor tissues from patients with the carcinoid syndrome. Possible involvement in the increased frequency of bowel movements. Scand 7 Gastroenterol 1987; 22 : 1041-8

6 Fanchamps VA, Doepfner W, Weidmann H, Cerletti A. Pharmakologische charakterisierung von deseril einem serotonin-antagonisten. Schweiz Med Wochenschr 1960.90. $1044-6$

7 Satterlee WG, Serpick A, Bianchine JR. The carcinoid syndrome: chronic treatment with para-chlorophenylanine. Ann Intern Med 1970; 72:919-21.

8 Sjoerdsma A, Lovenberg W, Engelman K, Carpenter WT, Wyatt RJ, Gessa GL. Serotonin now: clinical implications of Wyatt RJ, Gessa GL. Serotonin now: clinical implications of
inhibiting its synthesis with para-chlorophenylanine. Ann inhibiting its synthesis with

9 Biörck S, Ahlman H, Dahlström A, Phillips SF, Kelly KA Serotonergic regulation of canine enteric motility (measured 
as electrical activity) and absorption: physiologic and morphologic evidence. Acta Physiol Scand 1988; 133: $247-$ 56.

10 Pilot MA, Thompson HH, Zara GP. Effect of 5-hydroxytryptamine on canine intestinal motility during fasting. xytryptamine on canine intestinal

11 Hendrix TR, Atkinson M, Clifton JA, Ingelfinger FJ. The effect of 5-hydroxytryptamine on intestinal motor function in man. Am f Med 1957; 23: 886-93.

12 Sauer WG. Carcinoidosis and the effect of serotonin on the gastrointestinal tract. American Fournal of Digestive Disease 1961; 6: 906-13.

13 Camilleri M, Thomforde G, Minske D, Vassallo M, Powers S Kvols L. Gastrointestinal transit, colonic capacitance and possible mediators in carcinoid diarrhoea. Gut 1991; 32: A1248.

14 Bülbring E, Lin RCY. The effect of intraluminal application of 5-hydroxytryptamine and 5-hydroxytryptophan on peristalsis; the local production of $5-\mathrm{HT}$ and its release in relation to intraluminal pressure and propulsive activity. F Physiol 1958; 140: 381-407.

15 Kosterlitz HW, Robinson JA. Inhibition of the peristaltic reflex of the isolated guinea pig ileum. F Physiol (Lond) 1957 136: 249-62.

16 Costa M, Furness JB. The sites of action of 5-hydroxytryptamine in nerve-muscle preparations for the guinea-pig small intestine and colon. Br f Pharmacol 1979; 65: 237-48.

17 Bradley PB, Engel G, Feniuk W, Fozard JR, Humphrey PPA Middlemiss DN, et al. Proposals for the classification and nomenclature of functional receptors for 5-hydroxytryptamine. Neuropharmacology 1986; 25: 563-76.

18 Dumuis A, Bouhelal R, Sebben M, Cory R, Bockaert G. A nonclassical 5-hydroxytryptamine receptor positively coupled with adenylate cyclase in the central nervous system. Mol Pharmacol 1988; 34:880.

19 Craig DA, Clarke DE. Pharmacological characterisation of neuronal receptor for 5-hydroxytryptamine in guinea-pig ileum with properties similar to the 5-hydroxytryptamine receptor. F Pharmacol Exp Ther 1990; 252: 1378

20 Eglen RM, Swank SR, Dubuque LK, Whiting RL Characterisation of $5 \mathrm{HT}$ receptors mediating contractions of guinea pig ileum in vitro. Brf Pharmacol 1990; 99: 216P.

21 Elswood CJ, Bunce KT, Humphrey PPA. Identification of putative 5HT-4 receptors in guinea-pig ascending colon. Eur F Pharmacol 1991; 196: 149-55.

22 Bom AH, Duncker DJ, Saxena PR, Verdouw PD. 5-hydroxytryptamine-induced tachycardia in the pig: possible involvement of a new type of 5-hydroxytryptamine receptor. BrF Pharmacol 1988; 93: 663-71.

23 Villalón CM, den Boer MO, Heiligers JPC, Saxena PR Mediation of 5-hydroxytryptamine-induced tachycardia in Mediation of 5 -hydroxytryptamine-induced tachycardia in the pig by the $665-7$.

24 Kaufmann AJ, Sanders L, Brown AM, Murray KJ, Brown $M J$. A 5-hydroxytryptamine receptor in human atrium. $\mathrm{Br} f$ Pharmacol 1990; 100: 879-85.

25 Buchheit KH, Engel G, Mutschler E, Richardson B. Study of the contractile effect of 5-hydroxytryptamine $(5-\mathrm{HT})$ in the isolated longitudinal muscle strip from guinea-pig ileum. Evidence for two distinct release mechanisms. Naunym Schmeidebergs Arch Pharmacol 1985; 329: 36-41.

26 Phillips SF, Quigley EMM, Kumar D, Kamath PS. Motility of the ileocolonic junction. Gut 1988; 29: 390-406.

27 von der Ohe $M$, Camilleri $M$, Kvols LK, Vassallo MJ Thomforde GM. Accelerated intestinal transit and reduced proximal colonic volume in carcinoid diarrhea. Gastroproxiology 1992; 102: A251.

28 Thomforde GM, Camilleri M. Effect of putative mediators of carcinoid diarrhea on upper gastrointestinal transit. Gastroenterology 1992; 102: A526.
29 Fanchamps VA, Doepfner W, Weidmann H, Cerletti A. Pharmakologische charakterisierung von deseril, einem serotonin-antagonisten. Schweiz Med Wochenschr 1960; 90 1044-6.

30 Lidberg P, Dahlstrom A, Ahlman H. Is $5 \mathrm{HT}$ a mediator in the motor control of the feline pylorus? Scand $\mathcal{F}$ Gastroenterol 1984; 19: 321-8.

31 Gullikson G, Virina M, Loeffler R, Yang D, Goldstin B Monroy $M$, et al. Differential gastrointestinal responses of the $\mathrm{S}$ and $\mathrm{R}$ isomers of Zacopride, a $5-\mathrm{HT}_{4}$ agonist and 5 $\mathrm{HT}_{3}$ antagonist. Gastroenterology 1991; 100: A446.

32 Gullikson GW, Loeffler RF, Yang DC, Virina MA, Goldstin B, Flynn DL, et al. Stereoselective 5-HT4 receptor agonism and GI prokinetic activity is demonstrated by $\mathrm{SC}-53116$, the active isomer of SC-49518. (jastroenterology 1992; 102: A455.

33 Miller MS, Galligan JJ, Burks TF. Accurate measurement of intestinal transit in rat. F Pharmacol Methods $1981 ; 6: 211-7$.

34 Ruytjens I, Thomforde GM, Camilleri M, Chapman NJ Effect of chemical symptathectomy on scintigraphic gastric
and small bowel transit in the rat. F Auton Nerv Syst 1992; 39: 111-8.

35 Rubin MR, Cardwell BA, Ouyang A, Snape WJ, Cohen S Effect of bethanechol or vegal nerve stimulation on ileocecal sphincter pressure in the cat. Gastroenterology 1981; 80 $974-9$

36 Ouyang A, Cohen S. Multiple 5-hydroxytryptamine receptors on feline ileum and ileocecal sphincter. Am F Physiol 1983 244: G426-34.

37 Gershon MD, Tamir H. Release of endogenous 5-hydroxytryptamine from resting and stimulated enteric neurons Neuroscience $1981 ; 6$ : 2277-86.

38 Freiling T, Cooke HT, Wood JD. Serotonin receptors for submucous neurons in guinea pig colon. Am F Physiol 1991; 261: G1017-23.

39 Jacoby HI, Bonfilio AC, Raffa RB. Central and peripheral administration of serotonin produces opposite effects on mouse colonic propulsive motility. Neurosci Lett 1991; 122 $122-6$

$40 \mathrm{Ng}$ WW, Jing J, Hyman PE, Snape WJ Jr. Effect of 5-hydroxytryptamine and its antagonists on colonic smooth muscle of the rabbit. Dig Dis Sci 1991; 36: 168-73.

41 Uguru MO, Bamgbose SO. Mechanisms of the relaxations induced by 5 -hydroxytryptamine on the rat isolated caecum. F Pharm Pharmacol 1986; 38: 140-3.

42 Goldberg M, Hanani M, Nissan S. Effects of serotonin on the internal anal sphincter in vivo manometric study in rats. Gut 1986; 27: 49-54.

43 Boeckxstaens GE, Pelckmans PA, Rampart M, Bogers JJ Verbeuren TJ, Herman AG, et al. Pharmacological characterization of 5 -hydroxytryptamine receptors in the characterization of 5-hydroxytryptamine receptors in the Exp Ther 1990; 254: 652-8.

44 Costall B, Naylor RJ. 5-Hydroxytryptamine: new receptor and novel drugs for gastrointestinal motor disorders. Scand $\mathcal{f}$ Gastroenterol 1990; 25: 769-87.

45 Peart WS, Robertson JIS. The effect of a serotonin antagonis (UML491) in carcinoid disease. Lancet 1961; ii: 1172-4.

46 Anderson JV, Coupe MO, Morris JA, Hodgson HJF, Bloom SR. Remission of symptoms in carcinoid syndrome with a new 5-hydroxytryptamine $M$ receptor antagonist. $B M \mathcal{J}$ 1987; 294: 1129.

47 Gustafsen J, Rendorf A, Raskor H, Boesby S. Ketanserin versus placebo in carcinoid syndrome. Scand $\mathcal{F}$ Gastroenterol 1986; $21: 816-8$.

48 Beubler E, Coupar IM, Hardcastle J, Hardcastle PT Stimulating effects of 5-hydroxytryptamine on fluid secretion and transmural potential differences in rat small intestine are mediated by different receptor subtypes. f Pharm Pharmacol 1992; 42: 35-9. 